\begin{tabular}{|l|l|l||}
\hline \multicolumn{2}{|c|}{ PublisherInfo } \\
\hline \hline PublisherName & $:$ & BioMed Central \\
\hline \hline PublisherLocation & $:$ & London \\
\hline \hline PublisherImprintName & $:$ & BioMed Central \\
\hline \hline
\end{tabular}

\title{
Airway resistance to cytokines
}

\begin{tabular}{|l|l|l||}
\hline \multicolumn{2}{|c|}{ ArticleInfo } \\
\hline \hline ArticleID & $:$ & 1600 \\
\hline \hline ArticleDOI & $:$ & $10.1186 /$ rr-2001-68492 \\
\hline \hline ArticleCitationID & $:$ & 68492 \\
\hline \hline ArticleSequenceNumber & $:$ & 11 \\
\hline \hline ArticleCategory & $:$ & Paper Report \\
\hline ArticleFirstPage & $:$ & 1 \\
\hline \hline ArticleLastPage & $:$ & 3 \\
\hline \hline & & RegistrationDate $: 2001-5-17$ \\
& $:$ & Received \\
\hline ArticleHistory & & Accepted 2001-5-17 \\
& $:$ 2001-9-13 \\
\hline \hline ArticleCopyright & $:$ & Biomed Central Ltd2001 \\
\hline \hline ArticleGrants & $:$ & \\
\hline \hline ArticleContext & $:$ & 129312211 \\
\hline \hline
\end{tabular}


Undurti Das, ${ }^{\text {Affl }}$

Corresponding Affiliation: Aff1

Aff1 EFA Sciences LLC, Norwood, MA, USA

Keywords

Asthma, ARDS, cytokines

\section{Context}

Both asthma and ARDS (acute respiratory distress syndrome) are characterized by inflammation and increased airway resistance. Tumor necrosis factor (TNF)-a and interleukin (IL)-1 are important mediators of inflammation and are known to play a role in asthma and ARDS. Earlier studies in guinea pigs reported that when TNF-a and IL-1 were used separately there is no change in airway resistance. In this study the authors investigated the possibility that TNF-a and IL-1 used together may influence airway resistance.

\section{Significant findings}

When added together to isolated perfused rat lungs, TNF-a and IL-1? caused a significant increase in airway resistance. Neither TNF-a nor IL-1?, when added to the perfusate individually, produced any remarkable change in the airway resistance. Induction of cyclooxygenase- 2 mRNA was observed on simultaneous treatment of lungs with TNF-a and IL-1?, which was blocked by prior treatment with dexamethasone. In addition, the TNF-a- and IL-1?-induced increase in airway resistance was associated with increased synthesis of thromboxane $\mathrm{A} 2\left(\mathrm{TxA}_{2}\right)$. A thromboxane receptor antagonist prevented TNF-a- and IL-1?-induced increases in airway resistance. These results suggest that these two cytokines can increase airway resistance and that $\mathrm{TxA}_{2}$ may be the mediator of this action. Hence, it is likely that $\mathrm{TxA}_{2}, \mathrm{TNF}-\mathrm{a}$ and IL-1? have a role in airway resistance that is seen in asthma and other inflammatory conditions.

\section{Comments}


Exposure to house dust endotoxin can predispose to the development of asthma. Endotoxin is a potent stimulator of TNF and IL synthesis. Based on the results of the present study, it can be suggested that endotoxin-induced increases in TNF-a and IL-1? secretion can enhance airway resistance. The importance of this work lies in the fact that TNF-a and IL-1? (which are produced together during inflammation) are produced in large amounts during several inflammatory conditions such as respiratory tract infections or ARDS, so airway resistance seen under these clinical circumstances could be attributed to these cytokines. Similarly, resistant bronchospasm seen in asthmatics with respiratory infection may partly be due to enhanced production of these cytokines. Future studies need to be performed using in vivo models in order to assess the role of specific $\mathrm{TxA}_{2}$ inhibitors or thromboxane receptor antagonists in modulating cytokine-induced airway hyperresponsiveness. Agents that block TxA2 synthesis may prove to be useful in the treatment of asthma.

\section{Methods}

Isolated perfused lung preparation, RT-PCR

\section{Additional information}

\section{References}

1. Martin C, Wohlsen A, Uhlig S: Changes in airway resistance by simultaneous exposure to TNF-a and IL-1? in perfused rat lungs. Am J Physiol Lung Cell Mol Physiol . 2001, 280: L595-L601.

This PDF file was created after publication. 